\title{
10 Minutes with Paul Hebert, Editor-in-chief of the Canadian Medical Association Journal
}

\author{
Pamela Verma, H.B.Sc., Diane Wu, H.B.Sc. \\ University of British Columbia, Vancouver, BC, Canada \\ *Corresponding Author: Pamela Verma; pamverma@interchange.ubc.ca
}

\begin{abstract}
Background: Most medical students, at some point in their career, aspire to publish a research paper of enough significance to join the pages of the major international medical journals. At the helm of these journals are physicians renowned for their academic and research acumen; in Canada, one of these physicians is Dr. Paul Hebert. We sat down with Dr. Hebert to talk about submission tips, becoming a journal editor, and how he got the job.

This feature is part of Editors in Medicine, an ongoing series within student medical journals. Other interviews will be published periodically in various student journals internationally.
\end{abstract}

\section{HOW DID YOU GET INTO EDITING?}

T guess my skill set for the job is largely because I was a senior researcher. There was a significant shortage of trained editors in this country and they had to find someone who wasn't of that category. My background is that of a critical care physician and clinical researcher, and I've basically become the editor of the CMAJ by default, I guess. It sounded like a great thing at the time.

\section{WHERE DO YOU SEE THE CMAJ GOING?}

Well, we've just written an editorial on that very issue and there are substantial challenges for all journals right now. The financial challenges are quite real, most print mass media have huge challenges because of diminishing advertising budgets, which is our lifeblood and funding. Our greatest threat is the financial one. My view is that most major medical journals will be primarily electronic in the future. Your generation is really looking to better electronic means of reading. So the question becomes, will we have a print journal at all? Will our journals be electronic only? I think we'll have a bridging period, but I think that's where we'll be in 10 or 15 years.

\section{AND IN TERMS OF THE TONE AND THE CONTENT OF THE CMAJ, WHERE DO YOU SEE THAT GOING?}

I think ideally what we want to do is to become far more international in our scope. Our goal is to disseminate 'medical knowledge that matters' - that's our tagline and we believe it - to the broadest possible audience, ideally to: physicians, decision-makers, policymakers, and to a general audience. We've democratised health information and knowledge in many ways, and my view is that it's a good thing. I see us communicating to an ever wider circle of readers including the general public.

\section{HOW CAN WE IMPROVE INTERNATIONAL REPRESENTATION IN PUBLISHING?}

There are a lot of possible answers to that question. One, there's no question that the leading medical journals publish primarily research of their own interest and in their own sphere. I think a lot more of it was based on pharmaceutical drug studies than possibly needed, that's largely because that's where the money comes from. Our revenue models do influence what we publish, whether we say it or not, in terms of broad agendas. I'm not saying we publish a study because it's funded by a drug company or not. I'm saying research of interest to the global health issues - we publish studies that are of far more relevance to our local audience. Frankly we all do it, with the possible exception of the Lancet. So when we compare the burden of disease globally to what we publish, there is usually a substantial disconnect. How to fix it? Well, acknowledge that it exists, first and foremost, actively seek to fix the problem, and start to solicit from other countries. But cost is a major driver right now.

\section{WHERE ARE THE GAPS IN TRAINING EDITORS RIGHT NOW?}

Well, the North American model for [recruiting] senior editors and editors-in-chief is typically distinguished scientists or distinguished academics going into the role of the editor. That's true at NEJM, it's true at JAMA, it's not true currently at Annals [of Internal Medicine], 
but it's true for me as well. So the reason for that in part is because that's what brings prestige to the journal. The downside of course is that the editor may or may not have the required training to actually assume the role when he or she starts. The British model is quite different; the editors are trained editors and they usually take on their roles after a long and distinguished career of editing. So that's the usual approach - they're full-time trained editors. Both have their advantages and disadvantages. For me, I'm far more at ease than most in the peer review process and in understanding how to fix and do research because I know how to do it; most of [the other editors] know how to report research. So it's a skill set that's far different, which is fine. But I have major deficiencies because of what I am. Pretty much anything to do with editing, I'm at a disadvantage with respect to others. The way that we make up for it is that we hire the best trained editors we can find ... and I get trained vicariously through them.

\section{WHAT ADVICE DO YOU HAVE FOR STUDENTS INTERESTED IN MEDICAL EDITING?}

It's like anything else - it's a skill you have to learn! Get involved in major medical journals, network with editors, take advantage of workshops. Medical editing is a small community. Working at a student journal is also a great way to get exposure.

Editors Comment: Since the composition of this article, Paul Hebert has announced that he will be stepping down from his position as Editor-in-chief of the CMAJ in December 2011.

\section{PET PEEVES - WHAT IS ONE THING ABOUT A SUBMISSION THAT DRIVES YOU CRAZY?}

I don't know if there's one - I think there's about 50 !

\section{OK, MAYBE YOUR TOP THREE.}

I don't know if there's anything that drives me crazy. What struck me when I became an editor - I was rather appalled by the quality of writing and the disconnect between what we publish and what we get initially. I was shocked by the degree of change that's required. You know, before I became an editor, I didn't know the difference between this and that. In part because our [research] group spent a fair bit of time getting stuff right before we submit. But I was shocked at how others don't. And that surprised me. I thought we were unique, and then I went to several other journals, and I realized we weren't. I just find it interesting or illuminating, I don't know if it's a pet peeve or not. I guess the one thing more than anything is how arrogant some people are. When you provide feedback for the betterment of their work and they just whine about it continuously.

\section{THREE WORDS TO DESCRIBE YOURSELF?}

Most people would say I'm quite energetic, relatively creative, and a reasonably good problem-solver.

\section{ANY REASON FOR THOSE WORDS?}

Those are kind of things other people say about me, I guess.

Medical Student Research Journal. (C) 2011. ISSN: 2159-3647. This is an Open Access article distributed under the terms of the Creative Commons AttributionNoncommercial-ShareAlike 3.0 Unported License. 